\title{
Explant Origin Affects the Frequency of Tetraploid Plants from Tissue Cultures of Melon
}

\author{
Jeffrey W. Adelberg and Bill B. Rhodes \\ Department of Horticulture, Clemson University, Clemson, SC 29634
}

Halina T. Skorupska

Department of Agronomy and Soils and Department of Biological Sciences, Clemson University, Clemson, SC 29634

William C. Bridges

Department of Experimental Statistics, Clemson University, Clemson, SC 29634

Additional index words. Cucumis melo, cotyledon, somaclonal variation, organogenesis, pollen

\begin{abstract}
Adventitious and axillary shoots of melon (Cucumis melo L.) were cultured from explants on a modified Murashige and Skoog medium containing $10 \mu \mathrm{M}$ BA. Explants were diversified with regard to genetic source (breeding lines Miniloup, L-14, and B-line), seed parts (apical and cotyledon tissue), seed maturity (10-40 days after pollination; DAP), and cotyledon sections with respect to apical-radicle axis (distal and proximal). Plants were screened for ploidy level by pollen morphometry. Immature cotyledons produced more tetraploid regenerants than mature cotyledons from seed of breeding line Miniloup; the highest frequency of tetraploid regenerant plants was from cotyledons of embryos harvested 18 and 22 DAP. Explants from the apical meristem of the same seeds produced fewer or no tetraploid plants. Proximal sections from immature cotyledons of three genotypes (Miniloup, L-14, B-line) produced higher frequencies of tetraploids than whole mature cotyledons or whole immature cotyledons.
\end{abstract}

Seed- and seedling-derived tissues of melon are used extensively as explants for research in micropropagation, genetic transformation, and germplasm enhancement via somaclonal variation. Among species in Cucurbitaceae, micropropagation has been used to propagate clonally diploid, triploid, and tetraploid genotypes of watermelon [Citrullus lanatus (Thunb.) Matsum. and Nakai] (Adelberg and Rhodes, 1989; Anghel and Rosu, 1985; Barnes, 1979; Compton et al., 1993). Genetic engineering has been used to obtain transgenic plants of C. sativus L. (Chee and Slightom, 1991) and C. melo (Fang and Grumet, 1990; Gonsalyes et al., 1994). Somaclonal variants, mainly tetraploids, have been identified among plants regenerated from cotyledons of $C$. melo and watermelon. Tetraploid variants of $C$. melo originated from adventitious shoots regenerated from cotyledons of immature (Adelberg et al., 1990) and mature seed (Boubdallah and Branchard, 1986; Fassuliotis and Nelson, 1992; Moreno and Roig, 1990; Wang et al., 1989), leaf explants (Kathal et al., 1992), protoplast-derived calluses (Debeuajon

Receivedforpublication26July 1993. Accepted for publication 20 Dec. 1993. Technical contribution no. 3446 of the South Carolina Agricultural Expt. Station, Clemson Univ., Clemson. S.C. The cost of publishing this paper was defrayed in part by the paymentofpage charges. Under postal regulations, this paper therefore must be hereby marked advertisement solely to indicate this fact. and Branchard, 1992), and somatic embryos derived from cotyledons of mature seed and shoot tips (Ezura et al., 1992). In watermelon, tetraploid plants were identified among adventitious shoots from immature (Adelberg et al., 1990) and mature seed embryos (Compton and Gray, 1993a) and regenerated from somatic embryos (Compton and Gray, 1993 b).

Wang et al. (1989) reported that cotyledons from melon seedlings contained $6.5 \%$ polyploid cells (mainly tetraploid) and $2 \%$ $30 \%$ of cells were polyploid and $51 \%$ were aneuploid. Differentiated shoots had $\approx 15 \%$ polyploid cells with root tips of regenerants containing $7 \%$ aneuploid cells. Induction of cell division in the quiescent cotyledon caused a variety of abnormal mitotic divisions. However, differentiation and plant development favored euploid variants and selected against aneuploids. Ezura and Oosawa (1994) have confirmed the selectivity of regeneration for euploid variants of melon in populations of callus with cells of variable ploidy. Percentage of polyploid plants from direct regeneration of leaf explants of melon increased during 1-3 months of subculture (Kathal et al., 1992). Adelberg (1993) examined independent regenerants from immature cotyledons for ploidy level 2 months after culture induction. Ten tissue lines cultured from basal buds of tetraploid or diploid regenerants, subculture monthly by enhanced axillary division over 18 months, did not increase in ploidy level and aneuploid cells. On callus-inducing medium, were nonchimeral with respect to ploidy (Adelberg et al., 1993). The original explant tissue, immature cotyledons, contained only diploid cells in $2 \mathrm{C}$ condition $\left(\mathrm{G}_{1}\right.$ or $\mathrm{G}_{0}$ of cell cycle). They concluded that induction of in vitro cell division coincided with endopolyploidization and that maintenance of ploidy level during subculture was stable. Many direct-adventive shoot systems give rise to nonchimeral plants under mutation-inducing conditions (George and Sherrington, 1984).

In our study, we determined the frequency of tetraploidy for melon plants from explants representing various developmental stages, tissue types, genotypes, and distal-proximal subsections. Documenting the effects of explant source on frequency of tetraploids would allow prediction of clonal stability or selection of explants for efficient tetraploid production.

\section{Materials and Methods}

Nugent (U.S. Dept. of Agriculture Vegetable Laboratory, Charleston, S. C.) provided three unrelated diploid breeding lines of melon: Minilotip (small, smooth-skinned fruit with orange flesh), L-14 (smooth-skinned, green flesh), and B-line (netted, orange flesh). Fruit were from hand-pollinated, greenhouse-grown vines. Immature seed explants were prepared for the two experiments. We used the same culture conditions, including environmental factors, subculture protocol, and vessel type, as described by Adelberg et al. (1993). In the first experiment, seed from Miniloup fruit were aseptically dissected $10,14,18,22,26$, 30 , and 34 days after pollination (DAP). After 5 weeks on induction medium $[10 \mu \mathrm{M} 6-$ benzyladenine (BA)], buds from eight apical and eight cotyledon explants were transferred to $1 \mu \mathrm{M}$ BA shoot development medium. After 5 weeks, these shoots were rooted ex vitro (Adelberg et al., 1993). The effect of explant developmental stage on percentage of tetraploid plants was examined. This experiment helped to select the developmental stages for the second experiment.

In the second experiment, explants of Miniloup, L-14, and B-line were obtained from fruit harvested 20 and 40 DAP. Explants from immature cotyledons (20 DAP) were either cultured whole or bisected into distal and proximal subsections by a lateral cut across the cotyledon and cultured separately. Mature cotyledon explants were prepared from seed collected from fruit 40 DAP using a procedure similar to that for whole immature cotyledons. Regenerants were initiated under conditions similar to those of the first experiment (on medium modified with $10 \mu \mathrm{M}$ BA for 5 weeks), after which independently regenerated buds were subculture on multiplication medium with $10 \mu \mathrm{M}$ BA for 4 weeks. Regenerants were rooted in vitro on medium with $5 \mu \mathrm{M}$ indole-3butyric acid (IBA) for 3 weeks. The rooted shoots were rinsed free of medium and acclimatized in a greenhouse as described by Adelberg et al. (1993).

Examination of ploidy level was based on pollen grain morphology. Pollen was fixed in $70 \%$ ethanol and stained with $1 \%$ potassium 


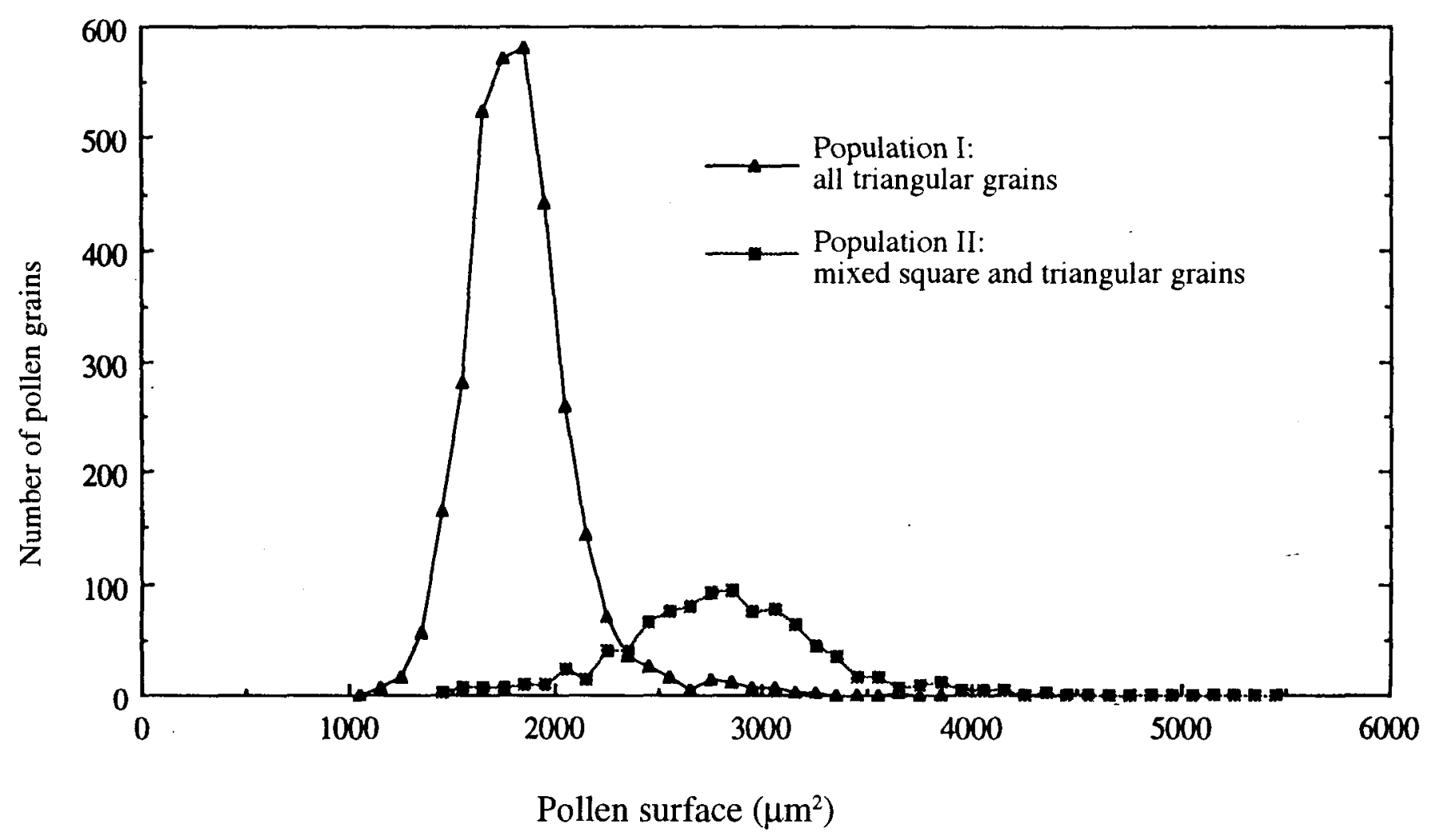

Fig. 1. Frequency histogram of surface area of melon pollen grains pooled from the genotypes L-14, Miniloup, and B-line. Errors for population I are $\alpha=0.04$ and $\beta=0.03$; for population II, $\alpha=0.12$ and $\beta=0.15$.

iodide. Morphometric determinations of pollen grain surface (Adelberg et al., 1993) were plotted to discern population characteristics of tetraploid variants. Tetraploid : diploid ratios from various explant sources were contrasted using $x^{2}$ analysis, categorical model procedure in SAS (SAS Institute, 1988). All calculations were performed on contingency of ploidy level from genotypes tested in regard to the explant sources. Specific hypotheses involving explant effects on ploidy, both across and within genotypes, were tested using subsets of the overall contingency data.

\section{Results and Discussion}

Male flowers on the first few nodes of plants from tissue culture produced pollen with size and shape similar to previous descriptions of diploid and tetraploid pollen of melon (Bartra, 1952; Fassuliotis and Nelson, 1992; Nugent and Ray, 1992). Two population types became apparent. Population I pollen grains had triangular shape, nearly uniform size, and positive iodide reaction for starch content, typical of diploid melons. Population II pollen grains were generally larger and varied in size more than population I pollen. Population $\mathrm{H}$ pollen also contained many four-sided pollen grains, typical of tetraploid variants. Other grains were nonstaining and aborted, also typical of tetraploid variants. Plants from the three melon genotypes produced populations of pollen grains with similar modal averages and variance for surface areas (Fig. 1). Population I represented diploid plants and had a modal average of $1950 \mu \mathrm{m}^{2}$ with $93 \%$ of the grains ranging between 1200 and $2200 \mu^{2}$. Population 11 had a modal average of $2850 \mu \mathrm{m}^{2}$ with $96 \%$ of the grains ranging between 1900 and $3800 \mu \mathrm{m}^{2}$. We concluded that the second population represented tetraploid plants. Morphometric quantification of six pollen grains from any individual plant allowed identification as diploid or tetraploid with a probability of type I or type II errors of $10^{-5}$ to $10^{-10}$ (Fig, 1).

The use of root-tip chromosomes to identify tetraploid plants is time consuming; therefore, alternative methods based on morphological observations have been developed for melon. These methods include determining cotyledon shape, internode length, leaf thickness, trichome density, stomata] length, number of chloroplasts per guard cell, flower size, blossom end scar, vein tracts on fruit, pollen shape and viability, and seed shape (Fassuliotis and Nelson, 1992; Nugent and Ray, 1992). Our study demonstrates that pollen shape and size are suitable indicators of ploidy level.

The percentage of tetraploid plants was higher for cotyledon-derived regenerants than for shoots grown from seed shoot apices (Table 1). The highest percentage of tetraploid regenerants was obtained from immature cotyledons of embryos collected 18 and 22 DAP (Table 1). No trend was observed for the small number of tetraploid plants from cultured seed shoot apices.

Proximal sections of immature cotyledons of L-14, Miniloup, and B-line produced higher proportions of tetraploid regenerants than whole mature cotyledons (Table 2). Also, in all three genotypes, proximal sections of im- mature cotyledons produced a higher percentage of tetraploid regenerants than whole immature cotyledons (demonstrated with $90 \%$ confidence). Inadequate population size may have caused difficulty in distinguishing significant comparisons. For example, only three regenerants were obtained from the distal portion of immature Miniloup cotyledons and identified as diploid, resulting in $100 \%$ diploid and $0 \%$ tetraploid regenerants. All comparisons to that population were significant. In contrasts involving the 349 regenerants of L-14, immature proximal explants produced a greater percentage of tetraploids than immature distal explants, and whole immature explants produced a greater proportion of tetraploids than whole mature explants. Miniloup, with 69 regenerants, followed the same trends, but statistical validity was not established for small populations. B-line, with 95 regenerants, did not display similar trends for frequency of tetraploid regenerants from the proximal and distal subsections or mature and immature cotyledons. Distal sections of cotyledons were more difflcult to regenerate for Miniloup and B-line.

Explanted proximal sections of immature cotyledons are a potential source of cells likely to produce tetraploid variants. Selection of proximal cotyledon sections for high regenerative ability has been observed with germinated Cucumis melo seedlings (Lesham, 1989). Explants of Citrullus lanatus, from proximal sections of immature cotyledons (Zhang et al., 1993) and mature cotyledons (Compton and Gray, 1993a; Tabei et al., 1993), regenerate shoots at a higher rate than distal regions. 
Table 1. Effects of explant developmental stage on the percentage of diploid (2n) and tetraploid (4n) plants obtained from cotyledon and shoot-tip explants of Miniloup. $^{2}$

\begin{tabular}{|c|c|c|c|c|c|c|c|c|c|c|c|c|c|c|c|c|}
\hline \multirow{3}{*}{$\begin{array}{l}\text { Explant } \\
\text { type }\end{array}$} & \multicolumn{14}{|c|}{$\mathrm{DAP}^{\mathrm{y}}$} & & \\
\hline & \multicolumn{2}{|c|}{10} & \multicolumn{2}{|c|}{14} & \multicolumn{2}{|c|}{18} & \multicolumn{2}{|c|}{22} & \multicolumn{2}{|c|}{26} & \multicolumn{2}{|c|}{30} & \multicolumn{2}{|c|}{34} & \multicolumn{2}{|c|}{ Total } \\
\hline & $2 \mathrm{n}$ & $\overline{4 n}$ & $2 n$ & $4 \mathrm{4n}$ & $2 n$ & $4 n$ & $2 n$ & $4 n$ & $2 n$ & $4 n$ & $2 n$ & $4 n$ & $2 n$ & $4 \mathrm{n}$ & $2 n$ & $4 n$ \\
\hline \multicolumn{17}{|c|}{ No. individual regenerants } \\
\hline Cotyledons & 0 & 0 & 4 & 2. & 10 & 10 & 10 & 10 & 18 & 5 & 26 & 6 & 14 & 1 & 82 & 34 \\
\hline Shoot apices & 0 & 0 & 2 & 0 & 10 & 0 & 19 & 2 & 12 & 0 & 17 & 0 & 31 & 1 & 91 & 3 \\
\hline \multicolumn{17}{|c|}{ Individual regenerants $(\%)$} \\
\hline Cotyledons ${ }^{x}$ & --- & --- & 67 & 33 & 50 & 50 & 50 & 50 & 78 & 22 & 82 & 18 & 93 & 7 & 71 & 29 \\
\hline Shoot apices ${ }^{x}$ & --- & --- & 100 & 0 & 100 & 0 & 91 & 9 & 100 & 0 & 100 & 0 & 97 & 3 & 97 & 3 \\
\hline Significance $^{w}$ & \multicolumn{2}{|c|}{---} & \multicolumn{2}{|c|}{ NS } & \multicolumn{2}{|c|}{ * } & & & \multicolumn{2}{|c|}{ NS } & \multicolumn{2}{|c|}{ NS } & \multicolumn{2}{|c|}{ NS } & \multicolumn{2}{|c|}{$* * *$} \\
\hline
\end{tabular}

${ }^{2}$ Explants-were cultured on modified MS medium with $10 \mu \mathrm{M} \mathrm{BA}$ for 5 weeks. Individual buds were transferred to $1 \mu \mathrm{M}$ BA shoot development media for 5 weeks and elongated shoots were rooted ex vitro.

Y DAP = Days after pollination.

${ }^{x}$ Analysis of variance showed no difference for effect of DAP on percentage of tetraploid plants from shoot apices and $P \leq 0.05$ for cotyledons. Logarithmic equation for DAP $(\mathrm{x})$ effects on percent tetraploid frequency $(\mathrm{y})$ from cotyledons, days $14-34 ; \mathrm{y}=0.548+0.337 \log \mathrm{x}+0.009 \log x^{2} ; R^{2}=0.94$.

"Explant type effect on percentage of tetraploid plants: significance by $\chi^{2}$ analysis.

${ }_{* s, * * *, * * *}$ Nonsignificant or significant at $P \leq 0.05,0.01,0.001$, respectively.

Effects of developmental stage of seed on regeneration of tetraploids showed immature cotyledons from embryos of fruit harvested 18 and 22 DAP produced the highest frequency of tetraploids. These observations should be considered when choosing the explant source for regeneration. If the goal of future experiments is to obtain a high frequency of tetraploid regenerants, then researchers should select an explant source that favors tetraploidy (e.g., proximal end of immature cotyledons). If the goal is to maintain purity with regard to ploidy, however, researchers should choose outgrowth of shoot-tip explants. As with many other plants systems, adventitious shoot formation allows somaclonal variation, and axillary branching maintains genomic stability (Hu and Wang, 1983; Swartz, 1991).

Researchers involved with genetic trans-

formation seek adventive shoot formation systems that would maintain genomic stability with regard to ploidy. Transformed regenerants from cotyledons of melon contained high proportions of tetraploids (Gonsalves et al., 1994). Osifo et al. (1989) report that cotyledon explants of many plant species produce tetraploid variants. Temporal and spatial factors during cotyledon development influence the likelihood of tetraploid induction. Understanding developmental patterns in cotyledon tissue preceding endopolyploidization is needed before this system can be manipulated with regard to tetraploid generation.

\section{Literature Cited}

Adelberg,J.W.1993. Tetraploid melon from tissue culture and their triploid hybrids. PhD Diss., ClemsonUniv.,Clemson, S.C.

Table 2. The effects of explant section and maturity on the frequency of diploid ( $2 n)$ and tetraploid $(4 n)$ regenerants from three genotypes of Cucumis melo. ${ }^{2}$

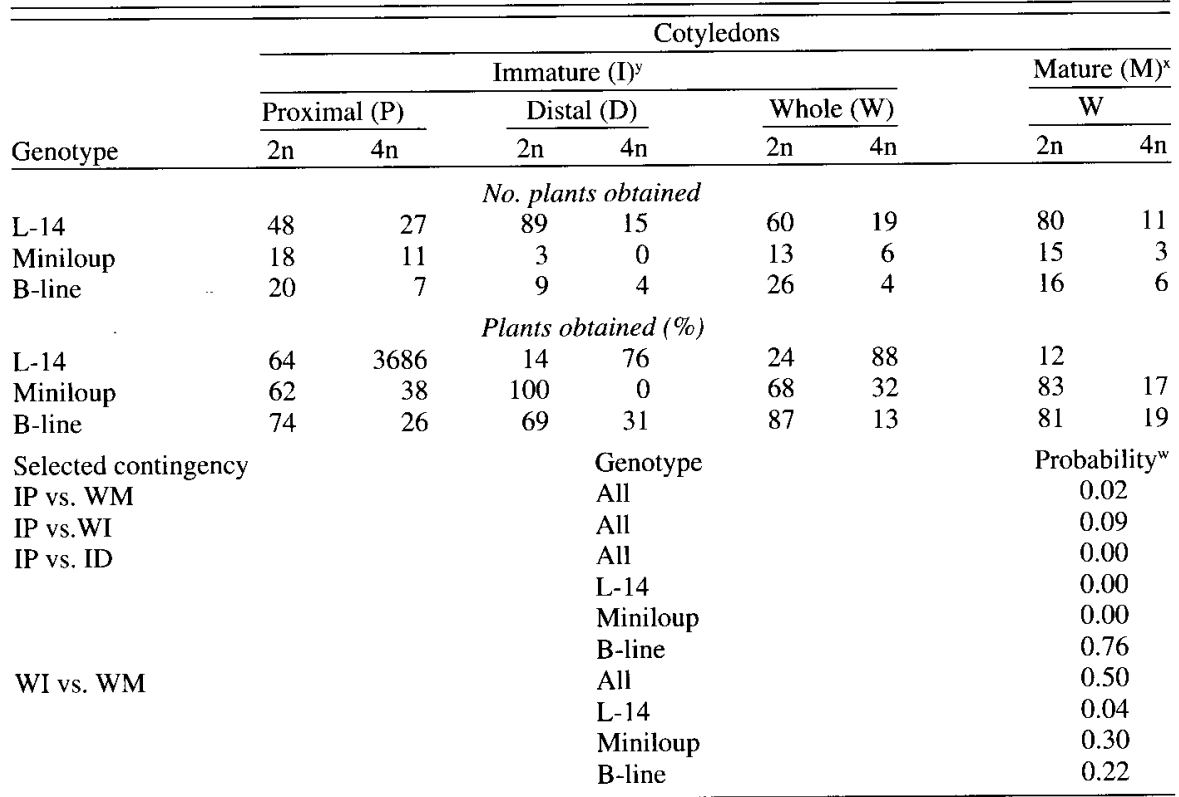

${ }^{2}$ Explants were incubated on modified MS medium with $10 \mu \mathrm{M}$ BA for 5 weeks. Regenerant buds were multiplied on MS medium with $10 \mu \mathrm{M}$ BA for 5 weeks and rooted in vitro on MS medium with $5 \mu \mathrm{M}$ IBA for 3 weeks.

${ }^{y}$ Explants were immature cotyledons from embryos harvested 20 days after pollination.

'Explants were whole cotyledons harvested 40 days after pollination.

"Probability that populations varied due to random chance as calculated from $\chi^{2}$ analysis.
Adelberg,J.W.and B.B. Rhodes. 1989. Micropropagation from zygotic tissues of watermelon, $\mathrm{p}$. 110-112. In: C.E. Thomas (cd.). Proc. of the Cucurbitaceae89:Evaluationandenhancement ofCucurbit germplasm. Charleston, S.C.

Adelberg, J. W., B.B. Rhodes, and H.T. Skorupska. 1990. Generating tetraploid watermelon and melon from tissue culture. HortScience 25:73. (Abstr.)

Adelberg, J.W., B.B. Rhodes, and H.T. Skorupska. 1993. Generatingtetraploidmelons from tissue culture. Acts Hort 336:373-380.

Anghel, I. and A. Rosu. 1985. In vitro morphogenesisindiploid,triploidand tetraploid genotypes of watermelon. Rev. Roumanian Biol.-Biol. Veg. 30:43-55.

Barnes, L.R. 1979. In vitro propagation of watermelon.ScientiaHort. 11:223-227.

Bartra,S.1952.Induced tetraploidy in muskmelon. J. Hered. 43:141-148.

Bouabdallah, L. and M. Branchard. 1986. Regenerationofplantsfromcallus culture of Cucumis melo L. Z. Pflanzenphysiol. 96:82-85.

Chee, P.P. and J.L. Slightom. 1991. Transfer and expression of cucumber mosaic virus coat protein gene in the genome of Cucumis sativus. J. Amer. Soc. Hort. Sci. 116:1098-1102.

Compton, ME. and D.J. Gray. 1993a. Shoot organogenesis and plant regeneration from cotyledons of diploid, triploid, and tetraploid watermelon. J. Amer. Soc. Hort. Sci. 118:151-157.

Compton M.E. and D.J. Gray. 1993b. Somatic embryogenesisandplantregenerationform immature cotyledons of watermelon. Plant Cell Rpt. 12:61-65.

Compton, M.E., D.J. Gray, and G.W. Elmstrom. 1993. Asimpleprotocolformicropropagating diploid and tetraploid watermelon using shoot-tip explants. Plant Cell Tissue Organ Cult. 33:211-217.

Debeaujon,I.and M. Branchard. 1992. Induction of caulogenesis from cotyledon and leaf protoplast derived colonies of melon (Cucumis melo L.). Plant Cell Rpt. 12:37-40.

Ezura,H.,H.Amagai, K. Yoshioka, and K. Oosawa. 1992.Highlyfrequentappearanceoftetraploidy in regenerated plants, a universal phenomenon intissueculturemelon (Cucumis melo L.). Plant Sci. 85:209-213.

Ezura,H.andK. Oosawa. 1994. Selective regenerationofplantsfromdiploidand tetraploid cells in adventitiousshootcultures of melon (Cucumis melo L.). Plant Tissue Cult. Lett. 11(1 ):26-33.

Fang, G. and R. Grumet. 1990. Agrobacterium tumefaciens mediated $\mathrm{Hz}>$ transformation and regeneration of muskmelon plants. Plant Cell Rpt. 9:160-164. 
Fassuliotis, G. and B. V. Nelson. 1992. Regeneration of tetraploid muskmelon cotyledon and their morphological difference for two diploid muskmelon genotypes. J. Amer. Soc. Hort. Sci. 117:863-866.

George, E.F. and P.D. Sherrington. 1984, Plant tissue culture, p. 1 -29. In: Plant propagation by tissue culture. Eastern Press, Reading, Great Britain,

Gonsalves, C., B. Xue, M. Yepes, M. Fuchs, K. Ling, S. Namba, P. Chee, J. Slightom, and D. Gonsalves. 1994. Transferring cucumber mosaic virus-white leaf strain coat protein gene into Cucumis melo L. and evaluating transgenic plants for protection against infections, J. Amer. Soc. Hort. Sci. 119:345-355.

$\mathrm{Hu}$, C.Y. and P.J. Wang. 1983. Meristem, shoot tip and bud culture, p. 124-176. In: D.A Evans, W.S. Sharp, P.V. Ammirato, and Y. Yamada (eds.), Handbook of plant cell culture vol. 1: Techniques for propa- gation and breeding. Macmillan, New York. Kathal, R., S.P. Bhantagar, and S.S. Bojwahni. 1992. Chromosome variants in the plants regenerated form leaf explants of Cucumis melo L. CV. 'Pusa Sharbati'. Caryologia 45(1):51-56.

Lesham, B. 1989. Polarity and responsive regions for regeneration in the cultured melon cotyledon. J. Plant Physiol. 135:237-239.

Moreno, V. and L.A. Roig, 1990, Somaclonal variation in Cucurbits, p. 435-464. In: Y.P.S. Bajaj (cd.). Biotechnology in agriculture and forestry, vol. 11: Somaclonal variation and crop improvement. Springer-Verlag, Berlin, Germany.

Nugent, P.E. and D.T. Ray. 1992. Spontaneous tetraploid melons. HortScience 27:47-50.

Osifo, E., J.K. Webb, and G.G. Henshaw. 1989. Variation amongst callus derived potato plants Solanum brevidens. J. Plant Physiol. 134:14.

SAS Institute. 1988. SAS/STAT user's guide. SAS Institute, Cary, NC.
Swartz, H.J. 1991. Post culture behavior: Genetic and epigenetic effects and related problems, p. 7 1-94. In: P.C. Debergh and R.H. Zimmerman (eds.). Micropropagation: Technology and application, Kluwer Academic Publishers, Dordecht, The Netherlands.

Tabei, Y., H. Yamanaka, and T. Kanno. 1993. Adventitious shoot induction and plant regeneration from cotyledons of mature seed in watermelon (Citrullus lanatus L.). Plant Tissue Cult. Lett. 10:235-241.

Wang, Y., Q. Gao, L. Wang, C. Liu, H. Yang, D. Wu, and Q. Zhang. 1989. Study on chromosome instability in tissue culture of Cucumis melo var. Inodorous (in Chinese), J. Lanzhou Univ. (Natural Sciences) 25(4):98-102.

Zhang, X. P., B.B. Rhodes, and J.W. Adelberg. 1994. Shoot regeneration from immature cotyledons of watermelon. Cucurbit Genetics Coop. (In press.) 